\title{
Bosentan Normalizes the GFR Response to Renal Nerve Stimulation Following Reversible Unilateral Ureteric Obstruction in the Rat
}

\author{
F. T. HAMMAD ${ }^{1,2}$ A. M. WHEATLEY ${ }^{2,3}$, G. DAVIS ${ }^{2}$ \\ ${ }^{1}$ Department of Surgery, Faculty of Medicine and Health Sciences, United Arab Emirates \\ University, Al Ain, UAE, ${ }^{2}$ Department of Physiology, Otago School of Medical Sciences, \\ University of Otago, Dunedin, New Zealand, ${ }^{3}$ Department of Physiology, School of Medicine, \\ National University of Ireland, Galway, Ireland
}

Received September 24, 2013

Accepted May 30, 2014

On-line August 26, 2014

\section{Summary}

We investigated the renal response to direct renal nerve stimulation, 2 weeks following reversal of 24-h unilateral (left) ureteric obstruction. Renal nerve stimulation caused a 13-15\% fall in renal blood flow, in 4 groups of anesthetized rats following ureteric obstruction $(n=9)$ or a sham operation $(n=7)$ both with $(n=9)$ and without $(n=7)$ treatment with the mixed $\mathrm{ET}_{\mathrm{A} / \mathrm{B}}$ receptor antagonist, bosentan. In the sham-operated rats, renal nerve stimulation did not change glomerular filtration rate but reduced urine flow rate $(37 \pm 3 \%, \mathrm{P}<0.001)$, and absolute $(38 \pm 4 \%$, $\mathrm{P}<0.001)$ and fractional $(35 \pm 5 \%, \mathrm{P}<0.01)$ sodium excretion. Following unilateral ureteric obstruction, renal nerve stimulation increased glomerular filtration rate by $22 \pm 3 \%(P<0.01)$, but reduced urine flow rate $(14 \pm 2 \%, \mathrm{P}<0.001)$ and fractional sodium excretion ( $23 \pm 5 \%, \mathrm{P}<0.01)$. Bosentan treatment had no effect on baseline or renal responses to renal nerve stimulation in the sham group but normalized the renal response to renal nerve stimulation in the unilateral ureteric obstruction group. We conclude that 14 days after a 24 -h period of unilateral ureteric obstruction there is an increase in GFR in response to direct renal nerve stimulation, which is due, in part, to the actions of endothelin at the time of obstruction.

\section{Key words}

Ureteric obstruction • Renal nerve stimulation • Bosentan

\section{Corresponding author}

G. Davis, Department of Physiology, Otago School of Medical Sciences, University of Otago, P. O. Box 913, Dunedin, New Zealand. Fax: +64 (03) 479 7323. E-mail: ged.davis@otago.ac.nz / gerard.davis@otago.ac.nz / geddavis@slingshot.co.nz

\section{Introduction}

Ureteric obstruction is a relatively common clinical problem which can lead to pain and ultimately to renal damage (Klahr et al. 1988). The renal damage is due to the interaction of various factors leading to afferent and efferent arteriolar vasoconstriction and alterations in glomerular and tubular function at the time of obstruction (Klahr et al. 1988, Hammad et al. 2000, Klahr 2001, Chevalier 2006, Hammad and Lubbad 2011). Several animal studies have been performed to investigate the alterations to renal function in the early stages (hours) after ureteric obstruction (Wright 1982, Klahr et al. 1988), however, few studies have addressed the longer-term effects of reversible ureteric obstruction on renal hemodynamics or tubular function. It has been shown that following reversal of a 24-h unilateral ureteric obstruction (UUO), renal blood flow (RBF), glomerular filtration rate (GFR) and absolute and fractional excretion of sodium returned to baseline by 14 days after the relief of the obstruction (Bander et al. 1985, Hammad et al. 2000). Although renal function returned to baseline, blockade of the renin-angiotensin system with Captopril lead to reductions in sodium and water excretion in the UUO rats, which contrasted with the diuresis and natriuresis observed in the sham animals (Hammad et al. 2000). Furthermore, infusion of physiological doses of angiotensin II $(25 \mathrm{ng} / \mathrm{kg} / \mathrm{min})$ resulted in an increase in GFR and diuresis and natriuresis (Hammad et al. 2000), suggesting that full humoral control of renal hemodynamics, and sodium and water excretion 
remained impaired up to 14 days following the reversal of the UUO. This inappropriate response to captopril and angiotensin II was prevented by peri-operative treatment with Bosentan, a non-selective endothelin $\mathrm{ET}_{\mathrm{A}} / \mathrm{ET}_{\mathrm{B}}$ receptor antagonist (Hammad et al. 2000). Others have shown that there is an increase in endothelin-1 mRNA expression $24 \mathrm{~h}$ following UUO (Hegarty et al. 2003). Furthermore, inhibition of endothelin-1 by a specific antibody significantly increased the GFR and effective renal plasma flow in rats immediately after reversal of a 24-h bilateral ureteric obstruction (Reyes and Klahr 1992). Collectively, this suggests that endothelin plays an important role in the renal response to ureteral obstruction, which has long-term consequences on renal function.

Renal sympathetic nerves innervate vascular and tubular structures throughout the kidney and are able to cause vasoconstriction and an increase in sodium and water reabsorption both by their direct action on the renal tubules and by increasing renin release and local angiotensin II concentration (DiBona and Kopp 1997).

Based on the observations from our previous study (Hammad et al. 2000), despite basal renal function returning to normal in the post obstructed kidneys, the possibility exists that, the neural control of renal function is impaired in the UUO animals. Therefore, the aim of this study was to investigate the long-term in vivo renal responses to direct renal nerve stimulation at 2 weeks following reversal of a 24-h UUO in the rat. In addition, we investigated the effect of ET-receptor blockade at the time of obstruction on the subsequent response to direct renal nerve stimulation.

\section{Materials and Methods}

Studies were performed on male Wistar rats weighing 228 to $248 \mathrm{~g}$ at the time of ureteric obstruction or sham operation. Animal procedures were approved by the University of Otago Animal Ethics Committee. Rats were kept in a $12 \mathrm{~h} \mathrm{light/dark}$ cycle at $20^{\circ} \mathrm{C}$, fed a standard rat chow and had water ad libitum.

\section{Ureteral occlusion/sham operation and reversal}

The following procedures were carried out under aseptic conditions. Induction of anesthesia was achieved by administering $4 \%$ Fluothane, (I.C.1., Zeneca, UK), in nitrous oxide and oxygen delivered at rates of $21 / \mathrm{min}$ and $31 / \mathrm{min}$, respectively. Surgical anesthesia was maintained by administration of $1.5-3.5 \%$ Fluothane in oxygen at a rate of $11 / \mathrm{min}$. The left kidney and ureter were exposed via a flank incision. As described previously (Hammad et al. 2000, Hammad and Lubbad 2011a,b), the ureter was obstructed by placing a 3-4 mm length of bisected P.V.C. tubing $(0.58 \mathrm{~mm}$ internal diameter $)$ around the left midureter, and occluding the tubing with a 4-0 silk suture. At the end of surgery, the wound was closed in layers.

Twenty-four hours later, all animals underwent reversal procedures. Using same anesthetic protocol as above, the left kidney and ureter were approached through the same incision. Using a dissecting microscope the obstructing tube was identified and removed. Full release of the obstruction was confirmed by observation of a free flow of urine across the site of obstruction. The wound was then closed.

Sham animals underwent identical surgical procedures except that the left ureter was cleared from surrounding tissue, without the occlusion.

\section{Bosentan administration}

Bosentan (Ro 47-0203/029, Roche, Switzerland), a mixed $\mathrm{ET}_{\mathrm{A} / \mathrm{B}}$ receptor antagonist, was administered orally (150 mg/kg/day) for 4 days commencing $24 \mathrm{~h}$ prior to obstruction or sham procedures and continued for 3 days after operation. The drug was mixed with a small quantity of pulverized rat chow $(5 \mathrm{~g})$, made into loose pellets by adding water and then drying at $37^{\circ} \mathrm{C}$. The pellets were placed inside the cage each evening and all other food was removed to ensure that the full dose of Bosentan was taken. The following morning, regular rat chow was made available after ensuring that each animal received the appropriate dose. Clozel et al. (1994) showed that the inhibitory action of $100 \mathrm{mg} / \mathrm{kg}$ Bosentan on the pressor response to ET-1 is effective for $24 \mathrm{~h}$, therefore, the $150 \mathrm{mg} / \mathrm{kg}$ oral dose used in this study would have remained effective throughout the treatment period (Clozel et al. 1994, Zuccarello et al. 1996).

\section{Surgical procedure in the terminal experiment}

Fifteen to eighteen days following reversal of the obstruction, rats were fasted overnight but had water ad libitum. Each animal was anesthetized with pentobarbitone sodium (Nembutal, Virbac, New Zealand) (60-70 mg/kg, i.p.) prior to the surgical procedure. Body temperature was maintained at $38^{\circ} \mathrm{C}$ by placing the animal on a heating plate and monitoring body temperature with a rectal thermometer. The trachea was cannulated with polyethylene tubing (PE-110, I.D., 
$1.50 \mathrm{~mm}$; O.D., $2.50 \mathrm{~mm}$ ) to reduce the possible complications arising from accumulation of mucus in the airway. Subsequently, a femoral vein was cannulated with polyethylene tubing (PE-45, I.D., $0.58 \mathrm{~mm}$; O.D., $0.96 \mathrm{~mm}$ ) through which a sustaining infusion of $0.9 \%$ saline and pentobarbitone sodium $(12.5 \mathrm{mg} / \mathrm{kg} / \mathrm{h})$ was established at a rate of $50 \mu \mathrm{l} / \mathrm{min}$ using an infusion pump (IITC Life Science, U.S.A.). A femoral artery was then cannulated (PE-45) and the tip of the cannula was positioned just below the level of the renal arteries and connected to a pressure transducer (Statham P23AC, Puerto Rico). The arterial blood pressure signal was amplified using a MacLab bridge amp (ADInstruments, Australia), digitized using a MacLab/4 (ADInstruments, Australia) and displayed on a Macintosh LCIII computer. The arterial cannula was also used to obtain blood samples, as required.

Through a midline lower abdominal incision, the bladder was exposed and cannulated with polyethylene tubing (PE-45) to drain urine from the right kidney to prevent renorenal reflexes. The left kidney was exposed through a flank incision and the proximal upper ureter was cannulated with polyethylene tubing (PE-10, I.D., $0.28 \mathrm{~mm}$; O.D., $0.61 \mathrm{~mm}$ ) for collection of urine in pre-weighed micro-capped tubes. The urine volume was determined gravimetrically. RBF was monitored continuously throughout the whole experimental protocol using a Doppler flowmeter (T206 flowmeter, Transonic Systems Inc., Itahaca, New York, U.S.A.). The renal nerves were visualized, transected, to eliminate neural reflex effects on renal function, and placed on bipolar stainless steel electrodes. The denervation was considered effective when the reduction in $\mathrm{RBF}$ in response to stimulation of the distal renal nerve was less than $10 \%$ of that observed prior to denervation (DiBona and Rios 1980).

On completion of the surgery, the sustaining infusion was replaced by one containing inulin $(1.5 \% \mathrm{w} / \mathrm{v})$. A priming dose of $2 \mathrm{ml}$ of the same solution was infused over $2 \mathrm{~min}$. Animals were allowed $2 \mathrm{~h}$ to equilibrate before being subjected to the experimental protocol.

\section{Experimental protocol}

The experimental protocol consisted of five $\mathrm{x}$ 15-min clearance periods: two before (basal) and two following (recovery) an experimental period (RNS) during which the renal nerves were stimulated. The stimulation period began $5 \mathrm{~min}$ prior to the clearance period, to allow for the elaboration of pre-formed urine, and continued throughout the clearance period. The renal nerves were stimulated by delivering square wave pulse at $20 \mathrm{~V}$, for $0.2 \mathrm{~ms}$ duration (Grass SD9 Stimulator, Quincy, MA, U.S.A.). Stimulation frequency ranged between 2.3 and $3.5 \mathrm{~Hz}$, to achieve a $13-15 \%$ reduction in RBF. The frequency of stimulation was adjusted as necessary through the course of the clearance period to ensure that the required RBF reduction was maintained. Similar frequencies were used in all the groups to achieve the same reduction in RBF. At the end of the experiment, the animals were euthanized with an overdose of barbiturate and the kidneys weighed.

Arterial blood samples $(400 \mu \mathrm{l})$ were taken at the beginning and end of the basal and recovery periods; immediately centrifuged and plasma $(125 \mu \mathrm{l})$ removed to be assayed at a later date. A $125 \mu$ l of saline replaced the plasma and the erythrocytes were re-suspended by gentle vortexing and the blood was returned to the animal. An additional 50-80 $\mu 1$ of blood was taken for hematocrit determination.

Urine and plasma samples were assayed for sodium using a flame photometer (SEAC Fp-20, Florence, Italy). Inulin content was determined using modified techniques described by Bojesen (1952). GFR was estimated from the clearance of inulin. All renal data were corrected for kidney weight $(\mathrm{g})$.

\section{Experimental groups}

Animals were divided into four groups: Sham group $(n=7)$ in which rats underwent manipulation of the left ureter only and served as a control group; the UUO group $(n=9)$ in which rats underwent left ureteric obstruction; B/Sham group $(n=7)$, in which rats underwent manipulation of the left ureter and received Bosentan treatment; and B/UUO group $(n=9)$, in which rats underwent left ureteric obstruction and received Bosentan treatment.

\section{Statistical analysis}

Statistical analysis was performed with the StatView 4.5 system (Abacus Concepts, Inc., Berkeley, CA, USA) designed for the Macintosh computer. All data are expressed as mean \pm SEM. Analysis of variance (ANOVA) with repeated measures was used to identify changes in each variable as a consequence of RNS. Comparison between groups was achieved using one-way ANOVA. A value of $\mathrm{P}<0.05$ was considered significant. 


\section{Results}

Basal mean arterial blood pressure and heart rate were similar in the four groups (Table 1) and did not change over the period of the protocol.

Table 1. Basal blood pressure and heart rate for Sham and unilateral ureteric obstructed animals treated with and without Bosentan.

\begin{tabular}{lcccc}
\hline & $\begin{array}{c}\text { Sham } \\
(\mathbf{n = 7})\end{array}$ & $\begin{array}{c}\text { UUO } \\
(\mathbf{n}=9)\end{array}$ & $\begin{array}{c}\text { B/Sham } \\
(\mathbf{n}=7)\end{array}$ & $\begin{array}{c}\text { B/UUO } \\
(\mathbf{n = 9})\end{array}$ \\
\hline $\begin{array}{l}\mathrm{MABP} \\
(\mathrm{mm} \mathrm{Hg})\end{array}$ & $103 \pm 3$ & $104 \pm 4$ & $104 \pm 3$ & $101 \pm 2$ \\
$\begin{array}{l}\text { HR } \\
\left.\text { (beats } \mathrm{min}^{-1}\right)\end{array}$ & $388 \pm 13$ & $391 \pm 13$ & $379 \pm 18$ & $396 \pm 12$ \\
\hline
\end{tabular}

UUO, unilateral ureteric obstruction; MABP, mean arterial blood pressure; HR, heart rate. Data is mean $\pm \mathrm{SEM}, \mathrm{n}=$ number of animals.

\section{Effect of RNS on RBF (Fig. 1)}

During RNS, RBF decreased by $14.0 \pm 0.2 \%$ $(\mathrm{P}<0.001$ in each case $)$ in the four groups of animals. The stimulation frequency needed to achieve this decrease in RBF ranged between 2.3-3.5 Hz, and did not differ between experimental groups. RBF in the B/UUO group during the recovery period was significantly lower than basal values $(\mathrm{P}<0.01)$, whereas $\mathrm{RBF}$ returned to pre-stimulus values in the other groups.
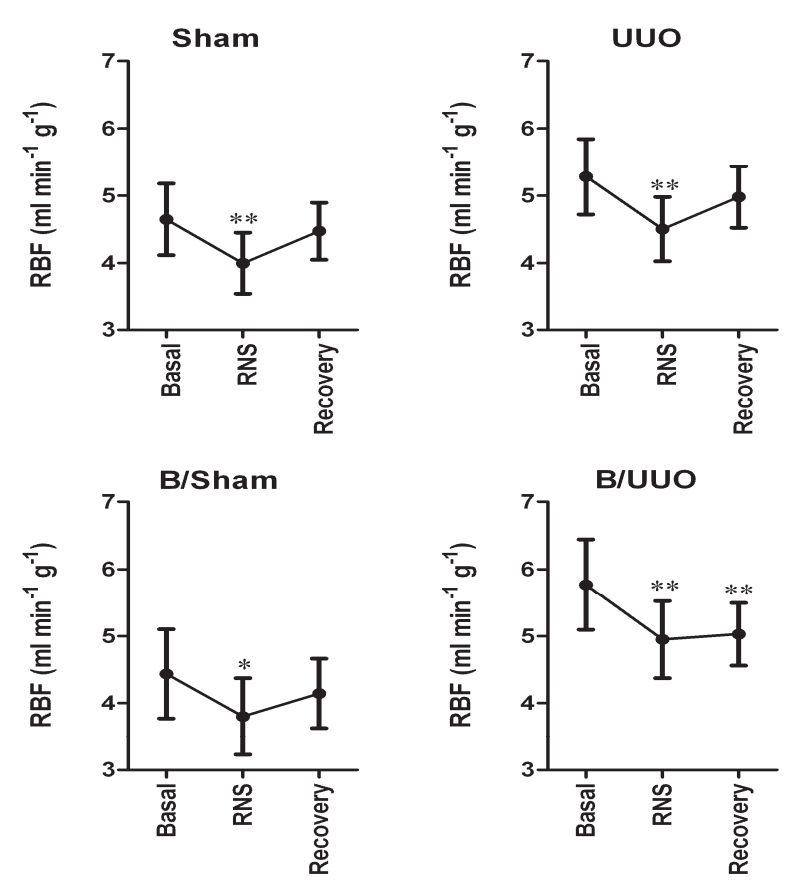

Fig. 1. Renal blood flow (RBF) responses to direct renal nerve stimulation (RNS) in the various groups. Asterisk (*) indicates statistical significant difference from Basal; $* \mathrm{p}<0.05, * * \mathrm{p}<0.01$.
Effect of RNS on GFR (Fig. 2)

RNS had no effect on GFR in the Sham, B/Sham or B/UUO groups; however, in the UUO group RNS increased GFR by $22 \pm 3 \%(\mathrm{P}<0.01)$. This response was significantly different from the Sham group $(\mathrm{P}<0.01)$. GFR in the B/UUO group during the recovery period was significantly lower than basal values $(\mathrm{P}<0.001)$, whereas GFR returned to pre-stimulus values in the other groups.
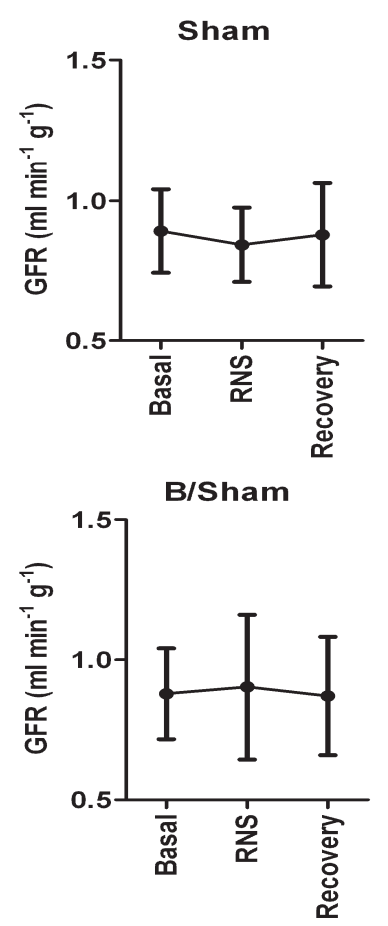
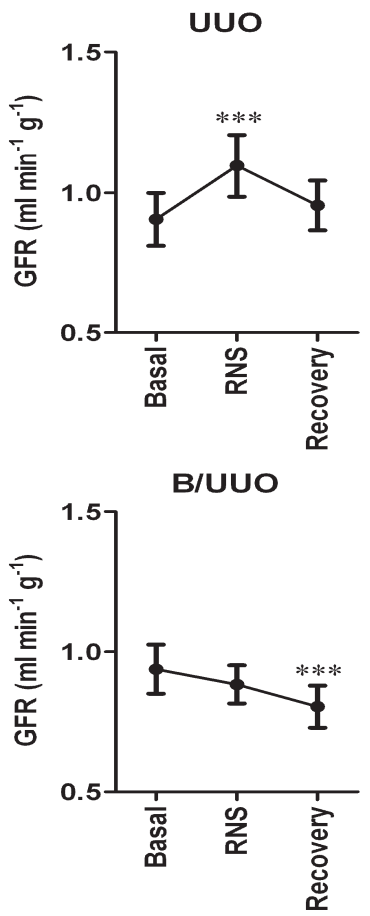

Fig. 2. Glomerular filtration rate (GFR) responses to direct renal nerve stimulation (RNS) in the various groups. Asterisk $\left({ }^{*}\right)$ indicates statistical significant difference from Basal; $* * * \mathrm{p}<0.0001$.

\section{Effect of RNS on UV (Fig. 3)}

RNS resulted in a decrease in UV in the Sham group $(37 \pm 3 \%, \quad \mathrm{P}<0.001), \mathrm{B} / \mathrm{Sham}$ group $(31 \pm 7 \%$, $\mathrm{P}<0.05)$ and $\mathrm{B} / \mathrm{UUO}$ group $(37 \pm 3 \%, \mathrm{P}<0.01)$. In the UUO group, the decrease in UV was $14 \pm 2 \%(\mathrm{P}<0.001)$, a smaller response compared to the Sham group $(\mathrm{P}<0.01)$.

\section{Effect of RNS on UNaV (Fig. 4)}

RNS resulted in a decrease in $\mathrm{U}_{\mathrm{Na}} \mathrm{V}$ in the Sham group $(38 \pm 4 \% \quad \mathrm{P}<0.001), \mathrm{B} / \mathrm{Sham}$ group $(34 \pm 7 \%$, $\mathrm{P}<0.01)$ and $\mathrm{B} / \mathrm{UUO}$ group $(39 \pm 4 \%, \mathrm{P}<0.01)$. In the UUO group there was no significant change in $\mathrm{U}_{\mathrm{Na}} \mathrm{V}$ in response to RNS. This response was significantly smaller than that measured in the Sham group $(\mathrm{P}<0.01)$. 


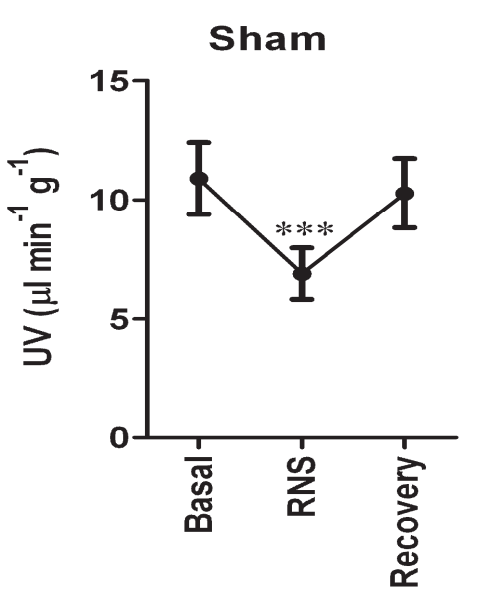

B/Sham

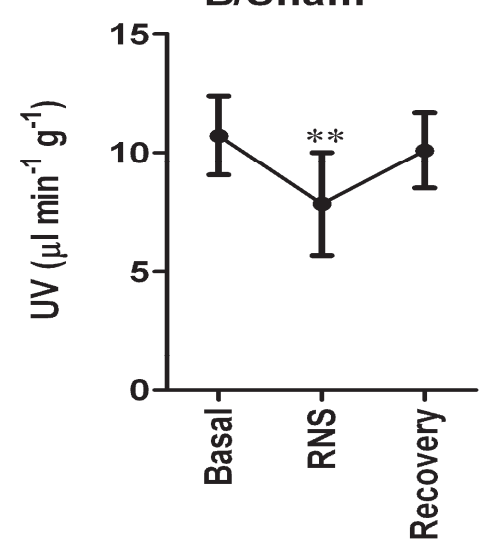

Sham

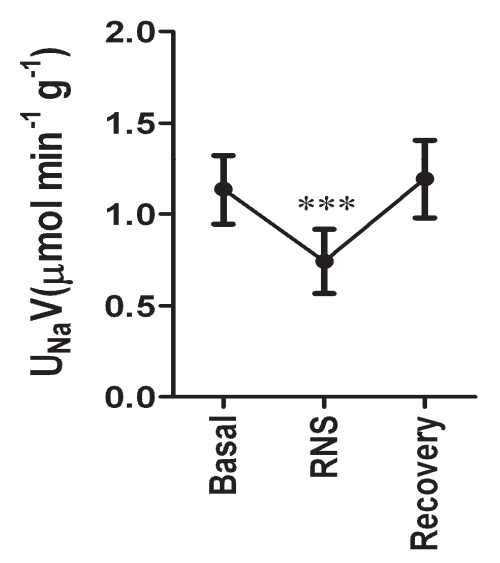

B/Sham

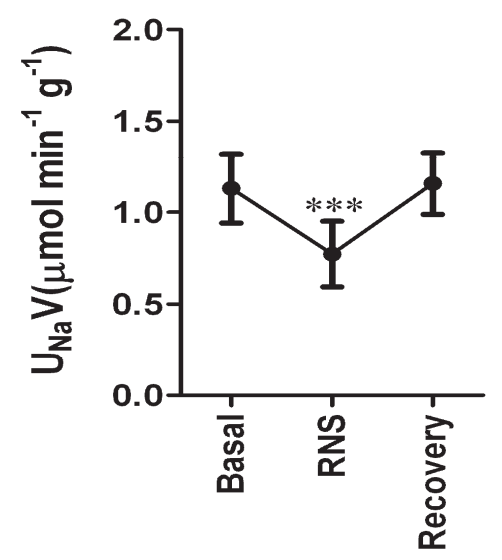

UUO

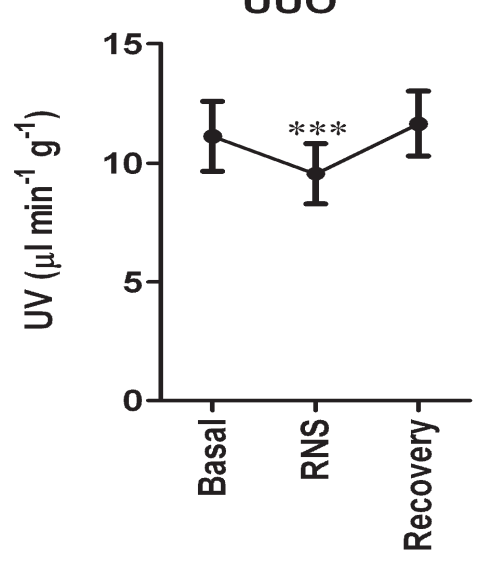

B/UUO

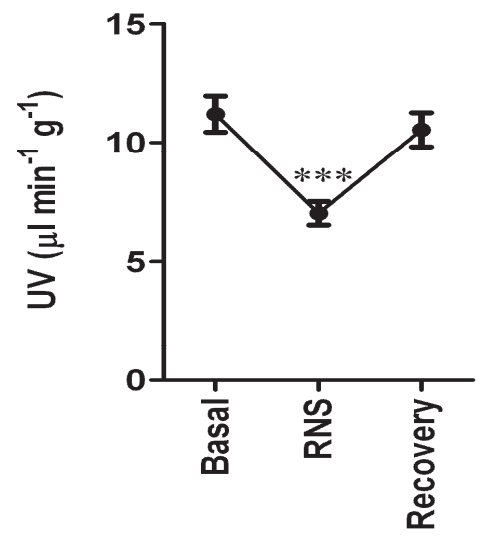

UUO

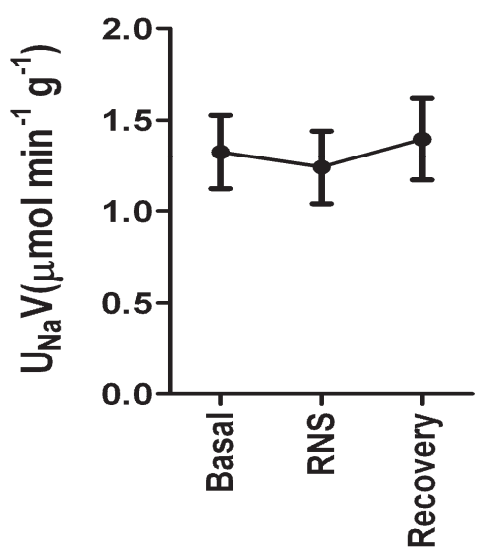

B/UUO

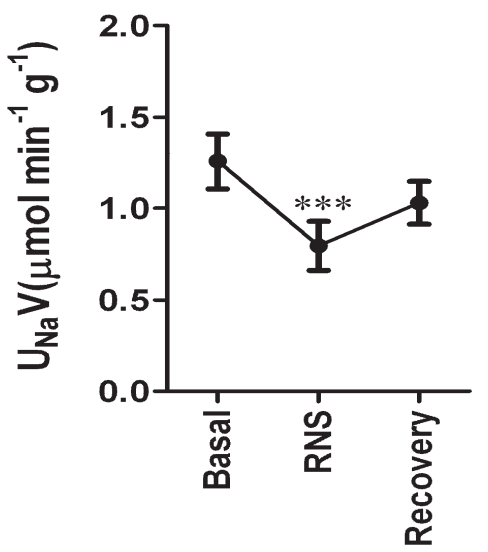

Fig. 3. Urine flow rate (UV) responses to direct renal nerve stimulation (RNS) in the various groups. Asterisk $(*)$ indicates statistical significant difference from Basal; $* * \mathrm{p}<0.01$, $* * * p<0.0001$.
Fig. 4. Absolute sodium excretion $\left(\mathrm{U}_{\mathrm{Na}} \mathrm{V}\right)$ responses to direct renal nerve stimulation (RNS) in the various groups. Asterisk (*) indicates statistical significant difference from Basal; $* * * p<0.0001$. 

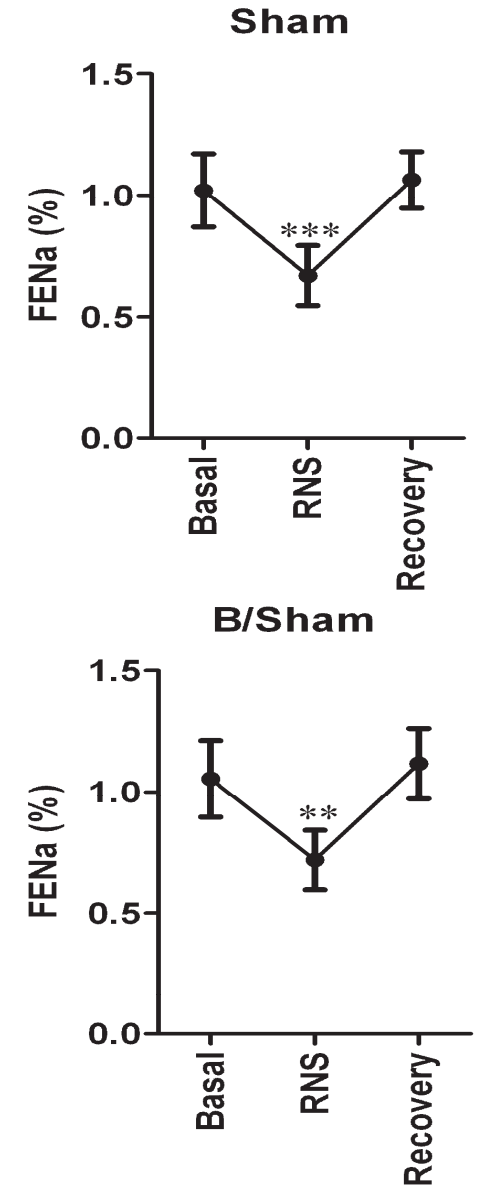

\section{Effect of RNS on FENa (Fig. 5)}

RNS resulted in a decrease in $\mathrm{FE}_{\mathrm{Na}}$ in the Sham group $(35 \pm 5 \%, \quad \mathrm{P}<0.01), \mathrm{B} /$ Sham group $(32 \pm 4 \%$, $\mathrm{P}<0.01)$ and $\mathrm{B} / \mathrm{UUO}$ group $(36 \pm 5 \%, \mathrm{P}<0.01)$. In the UUO group RNS resulted in a $23 \pm 5 \%(\mathrm{P}<0.01)$ decrease in $\mathrm{FE}_{\mathrm{Na}}$, which was significantly smaller than that observed in the Sham animals $(\mathrm{P}<0.01)$.

\section{Discussion}

The major finding from this study was that 14 days following the reversal of a 24-h UUO, RNS elicited a normal decrease in RBF but a simultaneous increase in GFR. This inappropriate increase in GFR was abolished by oral administration of the mixed $\mathrm{ET}_{\mathrm{A}} / \mathrm{ET}_{\mathrm{B}}$ receptor antagonist, bosentan in the peri-obstruction period.

In both the UUO and the sham animals RNS had no effect on MAP or HR. However, RNS resulted in a $14 \%$ fall in RBF in both groups, and the frequency of stimulation required to achieve this decrease in RBF was the same in both groups. In contrast to the response in the Sham group, the reduction in RBF in the UUO group was
UUO

Fig. 5. Fractional sodium excretion ( $\left.\mathrm{FE}_{\mathrm{Na}}\right)$ responses to direct renal nerve stimulation (RNS) in the various groups. Asterisk (*) indicates statistical significant difference from Basal; $* * \mathrm{p}<0.01, * * * \mathrm{p}<0.0001$.

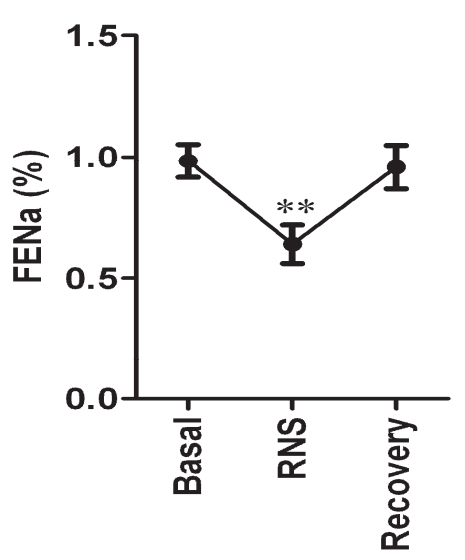


tend to increase more than afferent vascular resistance, and as a consequence, GFR would be maintained despite larger falls in RBF.

In the current study, RNS resulted in an increase in the GFR in the previously obstructed kidney. The exact reason for this abnormal response is difficult to ascertain from the current data. One possible explanation would be a preferential vasoconstriction of the efferent arterioles relative to the afferent arterioles in response to a rise in angiotensin II caused by RNS. In support of this, in an earlier study using the same unilateral ureteric obstruction model, we observed a marked increase in GFR in response to systemic infusion of a low dose of angiotensin II (Hammad et al. 2000). This preferential vasoconstriction of the efferent arterioles could be due to an alteration in the relative expressions of the two angiotensin II receptors (AT1 and AT2) in the afferent and efferent arterioles as suggested by some authors (Helou et al. 2003). It has long been shown that AT1 is responsible for the vasoconstriction effect of angiotensin II (Loutzenhiser et al. 1991, Arendshorst et al. 1999), whereas AT2 is responsible for the vasodilatation effect both in the afferent and efferent arterioles (Arima et al. 1997, Endo et al. 1997). Therefore, a down regulation of the AT1 receptors in the afferent arteriole as a result of ureteric obstruction could explain the rise in GFR due to RNS in the post-obstructed kidney. In this regard, several reports have shown that, following ureteric obstruction, there is a down regulation of $\mathrm{AT}_{1}$-receptors which are found mainly in the pre-glomerular vessels (Amiri and Garcia 1996, Ruan et al. 1997) and this was related to the profound activation of the renin-angiotensin system during the obstruction (Pimentel et al. 1994, 1995, Bae et al. 2007).

RNS in both the sham and UUO animals resulted in an antinatriuresis, as determined by $\mathrm{FE}_{\mathrm{Na}}$. However, there was no significant change in $U_{\mathrm{Na}} \mathrm{V}$ in the UUO animals. Further, while RNS in the UUO animals resulted in an antidiuresis, it was attenuated compared to that observed in the sham animals. The magnitude of response observed in the sham animals is consistent with previous report of RNS on tubular sodium and water handling (Hesse and Johns 1984). Collectively, the data suggests that nerve mediated tubular sodium and water handling was not significantly altered in the UUO animals, and the attenuated $\mathrm{UV}$ and $\mathrm{U}_{\mathrm{Na}} \mathrm{V}$ response was a result of the increase in GFR.

Treatment with the non-selective $\mathrm{ET}_{\mathrm{A} / \mathrm{B}}$ receptor antagonist, bosentan, during and in the early stages after the reversal of 24-h UUO led to normal renal hemodynamic and tubular responses to RNS 14 days later. Clearly, this indicates that endothelins are involved in the renal alterations which occurred due to obstruction and led to the altered response to RNS in the UUO group. This observation supports the findings of other researchers who have shown, in different models of obstruction, that ureteric obstruction caused an up-regulation of endothelins in the kidney (Josephson and Hemsen 1994, Hegarty et al. 2003, Bae et al. 2007) and an increase in their secretion in the urine produced by the obstructed kidney (Sharifian et al. 2013). Some other studies have even demonstrated a further increase of the endothelins immediately following reversal of a unilateral reversal of a 24-h bilateral ureteric obstruction (Reyes and Klahr 1992) or UUO (Bhangdia et al. 2003). Similar to the findings of this study, other reports have also demonstrated a beneficial effect of endothelin blockade in various pathophysiological renal conditions such as ischemia-reperfusion injury (Hammad et al. 2001a,b, Helmy et al. 2014, Lee et al. 2014). Despite this beneficial effect which was obtained in the current study, it is difficult to determine the exact endothelin receptor which was involved in this effect. However, it might be reasonable to state that it is more likely to be the $\mathrm{ET}_{\mathrm{A}}$-receptor because at least in the obstructed kidney, several studies using selective $\mathrm{ET}_{\mathrm{A}}$-receptor antagonists such as $\mathrm{BQ}-123$, have shown that the $\mathrm{ET}_{\mathrm{A}}$-receptor is the main receptor involved in the obstruction-induced vasoconstriction of the afferent arterioles (Endlich et al. 1996, Cavarape and Bartoli 1998, Bhangdia et al. 2003).

The exact mechanism for this beneficial effect of endothelin blockade is difficult to determine from this study although it is unlikely due to the direct effect of endothelins on the RNS. In this regards, Boesen and colleagues (2007), using a non-selective $\mathrm{ET}_{\mathrm{A}} / \mathrm{ET}_{\mathrm{B}}$ antagonist, demonstrated that endogenous endothelins did not appear to either augment or lessen the effects of renal nerve activation on total RBF, GFR or sodium excretion (Boesen et al. 2007). Alternatively, it could be due to the interaction with the renin-angiotensin system. Indeed, the beneficial effect of endothelins blockade in the current model might further demonstrate the importance of the interplay of the two systems (renin angiotensin system and endothelins) in the obstruction-induced renal alterations. This interaction between the two systems is well established in various tissues (Resink et al. 1990, Emori et al. 1991, Ito et al. 1993). In the kidney, endothelins blockade in vivo, inhibited the 
vasoconstrictor effect of angiotensin II (Balakrishnan et al. 1996, Riggleman et al. 2001, Wenzel et al. 2001). In addition, it has been suggested that the ability of ET antagonists $\left(\mathrm{ET}_{\mathrm{A}}\right.$ selective or non-selective $\left.\mathrm{ET}_{\mathrm{A}} / \mathrm{ET}_{\mathrm{B}}\right)$ to inhibit the in vivo actions of angiotensin II is most likely due to the angiotensin II-dependent release of ET-1 from the vascular endothelium (Kohan et al. 2011). Moreover, it has been suggested that $\mathrm{ET}_{\mathrm{A}}$ and $\mathrm{AT} 1$ receptors may heterodimerize to create interplay in post-receptor signalling. Collectively, endothelins appear to be important agents in eliciting angiotensin II-associated changes, such as the fall in RBF and GFR and the suggested down-regulation of the afferent arteriolar $\mathrm{AT}_{1}$-receptors. Blockade of the $\mathrm{ET}_{\mathrm{A}} / \mathrm{ET}_{\mathrm{B}}$-receptors, in the current study, might have prevented the sequence of events, during the period of UUO, which lead to a change in the intrarenal renin-angiotensin and endothelin systems. Consequently, normal renal function was observed during the recovery from the obstruction.

Although, there was no supportive data to directly verify that the bosentan dose used in this study (150 mg/kg/day) had totally blocked endothelin receptors, the fact that this dose had attenuated the alterations due to the ureteric obstruction implies that this dose was effective enough to bring such effects. Bosentan has a long half-life which means that the plasma levels remained in the therapeutic range throughout the treatment period (Clozel et al. 1994, Zuccarello et al. 1996). Furthermore, Similar dose was used in a previous study and had resulted in the desired effect (Hammad et al. 2000).

In the current study, we used this model of 24-h reversible unilateral ureteric obstruction which is similar to a clinical scenario of a transiently obstructing ureteric calculus. This model was chosen because this duration has been shown to be severe enough to cause a reversible renal damage (Bander et al. 1985, Hammad et al. 2000). However, one of the major drawbacks of this study is its descriptive nature and the inability to establish the exact mechanism which led to the alterations in renal functions in response to ureteric obstruction. Furthermore, it is not possible to establish which endothelin receptor subtype is responsible for this renal dysfunction. Additional studies,

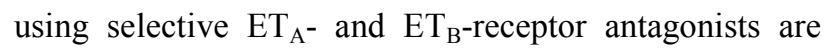
needed to throw further light on the topic.

In conclusion, two weeks following the reversal of a 24-h unilateral ureteric obstruction, baseline renal function had returned to normal. However, direct renal nerve stimulation resulted in an increase in GFR. We have also shown that this renal dysfunction can be abolished by non-selective $\mathrm{ET}_{\mathrm{A}} / \mathrm{ET}_{\mathrm{B}}$ endothelin receptor blockade at the time of the obstruction. These finding emphasize the close relationship between angiotensin II and endothelin in the pathogenesis of the unilateral ureteric obstruction.

\section{Conflict of Interest}

There is no conflict of interest.

\section{Acknowledgements}

The study was funded by the Department of Physiology. The authors would like to thank Dr. Chris Bolter (Department of Physiology, University of Otago) for constructive comments on the manuscript.

\section{References}

AMIRI F, GARCIA R: Differential regulation of renal glomerular and preglomerular vascular angiotensin II receptors. Am J Physiol 270: E810-E815, 1996.

ARENDSHORST WJ, BRANNSTROM K, RUAN X: Actions of angiotensin II on the renal microvasculature. $J A m$ Soc Nephrol 10 (Suppl 11): S149-S161, 1999.

ARIMA S, ENDO Y, YAOITA H, OMATA K, OGAWA S, TSUNODA K, ABE M, TAKEUCHI K, ABE K, ITO S: Possible role of P-450 metabolite of arachidonic acid in vasodilator mechanism of angiotensin II type 2 receptor in the isolated microperfused rabbit afferent arteriole. J Clin Invest 100: 2816-2823, 1997.

BAE EH, KIM IJ, PARK JW, MA SK, CHOI KC, LEE JU, KIM SW: Altered regulation of renin-angiotensin, endothelin and natriuretic peptide systems in rat kidney with chronic unilateral ureteral obstruction. Urol Int 79: 170-176, 2007.

BALAKRISHNAN SM, WANG HD, GOPALAKRISHNAN V, WILSON TW, MCNEILL JR: Effect of an endothelin antagonist on hemodynamic responses to angiotensin II. Hypertension 28: 806-809, 1996.

BANDER SJ, BUERKERT JE, MARTIN D, KLAHR S: Long-term effects of 24-hr unilateral ureteral obstruction on renal function in the rat. Kidney Int 28: 614-620, 1985. 
BHANGDIA DK, GULMI FA, CHOU SY, MOOPPAN UM, KIM H: Alterations of renal hemodynamics in unilateral ureteral obstruction mediated by activation of endothelin receptor subtypes. J Urol 170: 2057-2062, 2003.

BOESEN EI, ANDERSON WP, EVANS RG, KETT MM: Endogenous endothelins and the response to electrical renal nerve stimulation in anaesthetized rabbits. Auton Neurosci 132: 8-15, 2007.

BOJESEN E: A method for determination of inulin in plasma and urine. Acta Med Scand Suppl 266: 275-282, 1952.

CAVARAPE A, BARTOLI E: Effects of BQ-123 on systemic and renal hemodynamic responses to endothelin-1 in the rat split hydronephrotic kidney. J Hypertens 16: 1449-1458, 1998.

CHEVALIER RL: Pathogenesis of renal injury in obstructive uropathy. Curr Opin Pediatr 18: 153-160, 2006.

CLOZEL M, BREU V, GRAY GA, KALINA B, LOFFLER BM, BURRI K, CASSAL JM, HIRTH G, MULLER M, NEIDHART W, ET AL.: Pharmacological characterization of bosentan, a new potent orally active nonpeptide endothelin receptor antagonist. J Pharmacol Exp Ther 270: 228-235, 1994.

DENTON KM, LUFF SE, SHWETA A, ANDERSON WP: Differential neural control of glomerular ultrafiltration. Clin Exp Pharmacol Physiol 31: 380-386, 2004.

DIBONA GF, RIOS LL: Renal nerves in compensatory renal response to contralateral renal denervation. Am J Physiol 238: F26-F30, 1980.

DIBONA GF, KOPP UC: Neural control of renal function. Physiol Rev 77: 75-197, 1997.

EMORI T, HIRATA Y, OHTA K, KANNO K, EGUCHI S, IMAI T, SHICHIRI M, MARUMO F: Cellular mechanism of endothelin-1 release by angiotensin and vasopressin. Hypertension 18: 165-170, 1991.

ENDLICH K, HOFFEND J, STEINHAUSEN M: Localization of endothelin ETA and ETB receptor-mediated constriction in the renal microcirculation of rats. J Physiol 497: 211-218, 1996.

ENDO Y, ARIMA S, YAOITA H, OMATA K, TSUNODA K, TAKEUCHI K, ABE K, ITO S: Function of angiotensin II type 2 receptor in the postglomerular efferent arteriole. Kidney Int Suppl 63: S205-S207, 1997.

HALL JE, GUYTON AC, JACKSON TE, COLEMAN TG, LOHMEIER TE, TRIPPODO NC: Control of glomerular filtration rate by renin-angiotensin system. Am J Physiol 233: F366-F372, 1977.

HAMMAD FT, LUBBAD L: Does curcumin protect against renal dysfunction following reversible unilateral ureteric obstruction in the rat? Eur Surg Res 46: 188-193, 2011 a.

HAMMAD FT, LUBBAD L: The effect of diclofenac sodium on renal function in reversible unilateral ureteric obstruction. Urol Res 39: 351-356, 2011 b.

HAMMAD FT, WHEATLEY AM, DAVIS G: Long-term renal effects of unilateral ureteral obstruction and the role of endothelin. Kidney Int 58: 242-250, 2000.

HAMMAD FT, DAVIS G, ZHANG XY, WHEATLEY AM: Endotelin ETA and ETB receptor antagonism during cold preservation in renal transplantation. Transplantation 71: 619-627, 2001a.

HAMMAD FT, WHEATLEY AM, DAVIS G: Role of endothelin ET(A) receptor antagonism in the post-transplant renal response to angiotensin II in the rat. Exp Physiol 86: 365-372, $2001 \mathrm{~b}$.

HEGARTY NJ, YOUNG LS, O'NEILL AJ, WATSON RW, FITZPATRICK JM: Endothelin in unilateral ureteral obstruction: vascular and cellular effects. J Urol 169: 740-744, 2003.

HELMY MM, HELMY MW, ABD ALLAH DM, ABO ZAID AM, MOHY EL-DIN MM: Selective ET(A) receptor blockade protects against cisplatin-induced acute renal failure in male rats. Eur J Pharmacol 730: 133-139, 2014.

HELOU CM, IMBERT-TEBOUL M, DOUCET A, RAJERISON R, CHOLLET C, ALHENC-GELAS F, MARCHETTI J: Angiotensin receptor subtypes in thin and muscular juxtamedullary efferent arterioles of rat kidney. Am J Physiol Renal Physiol 285: F507-F514, 2003.

HESSE IF, JOHNS EJ: The effect of graded renal nerve stimulation on renal function in the anaesthetized rabbit. Comp Biochem Physiol A Comp Physiol 79: 409-414, 1984.

ITO H, HIRATA Y, ADACHI S, TANAKA M, TSUJINO M, KOIKE A, NOGAMI A, MURUMO F, HIROE M: Endothelin-1 is an autocrine/paracrine factor in the mechanism of angiotensin II-induced hypertrophy in cultured rat cardiomyocytes. J Clin Invest 92: 398-403, 1993.

JOHNS EJ, KOPP UC, DIBONA GF: Neural control of renal function. Compr Physiol 1: 731-767, 2011.

JOSEPHSON S, HEMSEN A: Renal tissue endothelin in long-term complete ureteric obstruction in the young rat. Urol Int 53: 57-61, 1994. 
KLAHR S: Urinary tract obstruction. Semin Nephrol 21: 133-145, 2001.

KLAHR S, HARRIS K, PURKERSON ML: Effects of obstruction on renal functions. Pediatr Nephrol 2: 34-42, 1988.

KOHAN DE, INSCHO EW, WESSON D, POLLOCK DM: Physiology of endothelin and the kidney. Compr Physiol 1: 883-919, 2011.

LEE TM, CHUNG TH, LIN SZ, CHANG NC: Endothelin receptor blockade ameliorates renal injury by inhibition of RhoA/Rho-kinase signalling in deoxycorticosterone acetate-salt hypertensive rats. $J$ Hypertens 32: 795-805, 2014.

LOUTZENHISER R, EPSTEIN M, HAYASHI K, TAKENAKA T, FORSTER H: Characterization of the renal microvascular effects of angiotensin II antagonist, DuP 753: studies in isolated perfused hydronephrotic kidneys. Am J Hypertens 4: 309S-314S, 1991.

PIMENTEL JL JR, WANG S, MARTINEZ-MALDONADO M: Regulation of the renal angiotensin II receptor gene in acute unilateral ureteral obstruction. Kidney Int 45: 1614-1621, 1994.

PIMENTEL JL JR, MONTERO A, WANG S, YOSIPIV I, EL-DAHR S, MARTINEZ-MALDONADO M: Sequential changes in renal expression of renin-angiotensin system genes in acute unilateral ureteral obstruction. Kidney Int 48: 1247-1253, 1995.

RESINK TJ, HAHN AW, SCOTT-BURDEN T, POWELL J, WEBER E, BUHLER FR: Inducible endothelin mRNA expression and peptide secretion in cultured human vascular smooth muscle cells. Biochem Biophys Res Commun 168: 1303-1310, 1990.

REYES AA, KLAHR S: Renal function after release of ureteral obstruction: role of endothelin and the renal artery endothelium. Kidney Int 42: 632-638, 1992.

RIGGLEMAN A, HARVEY J, BAYLIS C: Endothelin mediates some of the renal actions of acutely administered angiotensin II. Hypertension 38: 105-109, 2001.

RUAN X, WAGNER C, CHATZIANTONIOU C, KURTZ A, ARENDSHORST WJ: Regulation of angiotensin II receptor AT1 subtypes in renal afferent arterioles during chronic changes in sodium diet. $J$ Clin Invest 99: 1072-1081, 1997.

SHARIFIAN M, AHMADI M, KARIMI A, ZAND RE, MOGHADAR R, AHMADI R, CHIMEH MD: Urinary endothellin-1 level in children with pyelonephritis and hydronephrosis. Saudi J Kidney Dis Transpl 24: 731-736, 2013.

WENZEL RR, RUTHEMANN J, BRUCK H, SCHAFERS RF, MICHEL MC, PHILIPP T: Endothelin-A receptor antagonist inhibits angiotensin II and noradrenaline in man. Br J Clin Pharmacol 52: 151-157, 2001.

WRIGHT F: Effects of urinary obstruction on glomerular filtration rate and renal blood flow. Semin Nephrol 2: 5-16, 1982.

ZUCCARELLO M, SOATTIN GB, LEWIS AI, BREU V, HALLAK H, RAPOPORT RM: Prevention of subarachnoid hemorrhage-induced cerebral vasospasm by oral administration of endothelin receptor antagonists. J Neurosurg 84: 503-507, 1996. 